\section{Guarantee of Food Safety of Fat by Technology of Interesterification}

\section{Oltiev AT}

Bukhara Engineering-Technological Institute, Republic of Uzbekistan

"Corresponding author: A.T.Oltiev, Bukhara Engineering-Technological Institute, Republic of Uzbekistan, Tel: +998936587818; Fax: +998936587818; E-mail: azim-10-86@mail.ru

Received date: February 16, 2016; Accepted date: October 25, 2016; Published date: November 5, 2016

Copyright: ๑ 2016 Oltiev AT. This is an open-access article distributed under the terms of the Creative Commons Attribution License, which permits unrestricted use, distribution, and reproduction in any medium, provided the original author and source are credited.

\section{Introduction}

At reception of hard fats with the special purpose the particular attention is given to an arrangement of fat acids (acyls) in the molecule of triacylglycerides as their structurally-mechanical and rheological properties essentially depend on it [1]. It is known that process of hydrogenation is accompanied with interesterification of the fat acids, depending by nature of applied catalyst [2]

\section{Purpose of Work}

The work is devoted on research of hydrogenation and interesterification technology of cotton oil and products of its processing on highly effective catalysts and reception of safe food fats.

\section{Research Course:}

Researches on improvement of hydrogenation and interesterification technologies were made in laboratory and experimental-industrial plants [3]. The analysis and estimation of quality indicators of a chemical compound and arrangement of acyls in triacylglycerides were conducted by modern methods of physical and chemical research [4].

\section{Results and Discussion}

Results of research of interesterification activity of four disperse catalysts are presented at Table 1 . From Table 1 we can see that in triacylglyceride structure (TAG) of the refined cotton oil, as one would expect, sn-2-position on $95 \%$ is occupied by non-saturated acyls. The similar picture is observed in TAG of fat-oil, where sn-2-position by such acids etherified on 88-90\%. Concerning mono-oleic acids, it is necessary to notice that they almost identical etherify sn-1 and sn-3 positions. Mono-oleic acid is localized basically in sn-2-position and in sn-1. except TAG of hydrogenate.

\begin{tabular}{|c|c|c|c|c|c|}
\hline \multirow{2}{*}{ Product type } & \multirow{2}{*}{$\begin{array}{l}\text { Fat }^{*} \\
\text { Acids }\end{array}$} & \multicolumn{4}{|c|}{ The maintenance of acyls, mole $\%$} \\
\hline & & TAG & sn-1 & sn-2 & sn-3 \\
\hline \multirow{4}{*}{$\begin{array}{l}\text { The refined cotton oil } \\
\text { (The first sort) }\end{array}$} & $\mathrm{Cl} 6: 0$ & 28.8 & 44.0 & 4.7 & 36.9 \\
\hline & $C^{\prime} 18: 0$ & 1.5 & 2.4 & 0.3 & 0.3 \\
\hline & $C^{\prime} \mid 8: 1$ & 19.2 & 21.0 & 23.0 & 15.4 \\
\hline & $\mathrm{Cl} 8: 2$ & 50.5 & 32.6 & 72.0 & 47.4 \\
\hline \multirow{3}{*}{$\begin{array}{l}\begin{array}{l}\text { Fat-oil, received on } \\
\text { nickel- fossil meal } \\
\text { catalyst }\end{array} \\
\text { GM-3 }\end{array}$} & C16:0 & 29.6 & 40.5 & 5.6 & 40.3 \\
\hline & C' $18: 00$ & 4.9 & 6.1 & 5.0 & 7.3 \\
\hline & C' $18: 1$ & 51.1 & 43.3 & 67.7 & 44.7 \\
\hline
\end{tabular}

\begin{tabular}{|c|c|c|c|c|c|}
\hline & C18:2 & 14.4 & 10.1 & 21.7 & 7.7 \\
\hline \multirow{3}{*}{$\begin{array}{l}\text { Fat-oil, received on } \\
\text { nickel-copper catalyst } \\
\text { NM-4 }\end{array}$} & Cl6:0 & 29.4 & 41.8 & 5.4 & 40.0 \\
\hline & C'I8:0 & 6.2 & 7.0 & 4.8 & 6.4 \\
\hline & $C^{\prime} 18: 1$ & 50.6 & 39.9 & 69.5 & 45.1 \\
\hline & $C^{\prime} 18: 2$ & 13.8 & 11.3 & 20.3 & 8.5 \\
\hline \multirow{4}{*}{$\begin{array}{l}\begin{array}{l}\text { Fat-oil, received on the } \\
\text { nickel } \\
\text { HOECAT-882 FA }\end{array} \\
\text { catalyst }\end{array}$} & C16:0 & 29.7 & 40.3 & 5.7 & 40.5 \\
\hline & C'I8:0 & 4.8 & 6.0 & 5.1 & 7.4 \\
\hline & $C^{\prime} 18: 1$ & 51.3 & 43.5 & 67.9 & 44.9 \\
\hline & $C^{\prime} 18: 2$ & 14.2 & 10.2 & 21.3 & 7.2 \\
\hline $\begin{array}{lr}\text { Fat-oil, received on } \\
\text { nickel } & \text { catalyst } \\
\text { NYSOSEL-222 } & \end{array}$ & $\begin{array}{l}\text { Cl6:0 } \\
\text { C' } 18: 0 \\
\text { C' } 18: 1 \\
\text { C18:2 }\end{array}$ & $\begin{array}{l}29.9 \\
4.7 \\
51.0 \\
14.4\end{array}$ & $\begin{array}{l}40.4 \\
5.9 \\
43.4 \\
10.3\end{array}$ & $\begin{array}{l}5.8 \\
5.0 \\
67.7 \\
21.5 \\
5\end{array}$ & $\begin{array}{l}40.6 \\
7.2 \\
44.6 \\
7.6\end{array}$ \\
\hline
\end{tabular}

Note: C ' 18:0 - including the general maintenance of stearin and myristinic acids $\left(C^{\prime} 18: 0=C 16: 0+C 14: 0\right)$

C ' 18:1 - the general maintenance of monoenoic acids.

Table 1: Arrangement of fat acids TAG in sn-1. 2 and 3-positions in cotton oil and fat-oil depending on the catalyst nature.

As we see from Table 1 interesterification of fat acids in TAG occurs practically to all fat acids. Results of calculation of interesterification degree of investigated catalysts at reception of the modified fats are presented at Table 2 .

As we see from Table 2 the greatest regrouping of fat acids in TAG occurs on nickel catalyst NYSOSEL-222. Hence, on interesterification activity the studied catalysts can settle down in a following order of decrease: nickel catalyst NYSOSEL-222>nickel catalyst NOESAT-882 FA>nickel-fossil meal catalyst - GM3> nickel-copper the catalyst NM-4.

Research of various kinds of catalysts, has shown that the nickel catalysts restored and protected high-melting fat, have high enough hydrogenating, isomerization and interesterification activity that is very important at reception of firm fats of a special purpose.

The combination of processes hydrogenation cotton oil with the subsequent interesterification of fat-oil with vegetable oil is of interest at reception of fats from high food safety.

Therefore the expedient hydrogenate the cotton-palmitic oil, received by way of low-temperature fractionating of the refined cotton oil [5]. 
Citation: Oltiev AT (2016) Guarantee of Food Safety of Fat by Technology of Interesterification. J Exp Food Chem 2: 116. doi:

Page 2 of 3

\begin{tabular}{|c|c|c|c|c|c|}
\hline \multirow[t]{2}{*}{ Type of catalyst } & \multicolumn{3}{|c|}{ Maintenance of C16:0. \% } & \multirow{2}{*}{$\begin{array}{l}\text { П,\% } \\
\text { Р, \% }\end{array}$} & \multirow[t]{2}{*}{ Exponent } \\
\hline & MGo & MG & MG & & \\
\hline GM-3 & 4,7 & 5,6 & 0,9 & 19,2 & 3 \\
\hline NM-4 & 4,7 & 5,4 & 0,7 & 15,0 & 4 \\
\hline HOECAT 882 FA & 4,7 & 5,7 & 1,0 & 21,3 & 2 \\
\hline NYSOSEL 222 & 4.7 & 5,8 & 1,1 & 23,4 & 1 \\
\hline
\end{tabular}

Table 2: Interesterification abilities of catalysts at modifying of cotton oil.

The analysis of dilatometric characteristics of fat-oil has shown that hydrogenation of cotton-palmitic oil allows to receive fats with the raised maintenance high-melting TAG.

Proceeding from requirements to food safe hard fats received from vegetable oil, following conditions are accepted:

- The maintenance of firm glycerides in the mix of fat firm oil at temperature $70^{\circ} \mathrm{C}$ should be not less than $70 \%$;

- Offered firm fat in mix with oil in conditions of tempering should have stable $\beta$-form;
- Thermal effects at phase transitions in a mix of fat with oil should be characteristic for highly hard fat;

- The temperature of hardening of a mix of offered fat with oil on Jackson should be not lower than $28^{\circ} \mathrm{C}$.

Results of comparison mechanical and interesterificated mix of oil with fat-oil are presented at Table 3.

\begin{tabular}{|l|l|l|l|l|}
\hline \multirow{2}{*}{ Structure of a fatty mix } & \multicolumn{2}{l|}{ Mechanical mix before interesterification } & \multicolumn{2}{l|}{ Mix after interesterification } \\
\cline { 2 - 5 } & Melting temp, ${ }^{\circ} \mathbf{C}$ & Hardness., g/cm at $\mathbf{1 5}^{\circ} \mathbf{C}$ & Melting temp, ${ }^{\circ} \mathbf{C}$ & Hardness, $\mathbf{~} / \mathbf{c m}$ at $\mathbf{1 5 ^ { \circ } \mathbf { C }}$ \\
\hline Natural oil & 35.0 & 796.0 & - & - \\
\hline Highly hard cotton fat-oil & 37.6 & 580.0 & - & - \\
\hline Mix of highly hard fat-oil with oil at a parity 1:1 (50:50) & 35.5 & 585.5 & 33.0 & 578.5 \\
\hline Mix of highly hard fat-oil with oil at 1:2 (33.3:66.6) & 36.2 & 680.0 & 33.5 & 634.8 \\
\hline Mix of highly hard fat-oil with oil at 1:3 (25:75) & 36.5 & 692.0 & 33.8 & 683.4 \\
\hline Mix of highly hard fat-oil with oil at 1:4 (20:80) & 36.7 & 700.5 & 34.0 & 677.9 \\
\hline \multirow{2}{*}{ Mix of highly hard fat-oil with oil at 1:7 (12.5:87.5) } & 37.0 & 719.0 & 34.2 & 635.6 \\
\hline
\end{tabular}

Table 3: Physical and chemical indicators of the mix of natural cotton oil with highly hard fat-oil at various parities before and after interesterification.

From Table 3 we can see that entering of highly hard fat in quantity of $12.5 \%$ from a mix mass considerably reduces hardness of natural oil. The further growth of the maintenance of fat-oil leads to decrease on $25 \%$ of initial hardness of natural oil. Thus fats, received after interesterification, have fusion temperature on $2.0-3.0^{\circ} \mathrm{C}$ below initial, and their hardness after interesterification decreases slightly. Results of interesterification of mixes of highly hard fat-oil with cotton oil at various parties are presented at Table 4.

Data from Table 4 shows that introduction in structure of fat-oil at interesterification $10-15 \%$ of the refined cotton oil allow to lower its temperature of fusion to $34.5-36.0^{\circ} \mathrm{C}$. Thus hardness of the received fats remains at level of $790-897 \mathrm{~g} / \mathrm{cm}$ at $15^{\circ} \mathrm{C}$. The further increase in the maintenance of the refined cotton oil in a mix (more than $15 \%$ ) leads to sharp decrease in hardness of received highly hard fat.

Hence, combining processes of hydrogenation of product of processing of cotton oil with interesterification of received fat-oil with liquid oil, it is possible to receive the fats close on the indicators to highly hard fat. 
Citation: Oltiev AT (2016) Guarantee of Food Safety of Fat by Technology of Interesterification. J Exp Food Chem 2: 116. doi: 10.4172/2472-0542.1000116

Page 3 of 3

\begin{tabular}{|c|c|c|c|c|}
\hline \multirow{2}{*}{ Structure of a fatty mix } & \multicolumn{2}{|c|}{$\begin{array}{l}\text { Indicators of a mechanical mix before } \\
\text { interesterification }\end{array}$} & \multicolumn{2}{|c|}{ Indicators of a mix after interesterification } \\
\hline & Melting temp, ${ }^{\circ} \mathrm{C}$ & Hardness., $\mathrm{g} / \mathrm{cm}$ at $15^{\circ} \mathrm{C}$ & Melting temp, ${ }^{\circ} \mathrm{C}$ & Hardness., $\mathrm{g} / \mathrm{cm}$ at $15^{\circ} \mathrm{C}$ \\
\hline Highly hard cotton fat-oil & 44.5 & 930 & 41.3 & 905 \\
\hline Mix of highly hard fat-oil with cotton oil at a parity $95: 5$ & 43.0 & 905 & 38.0 & 897 \\
\hline Mix of highly hard fat-oil with cotton oil at 90:10 & 42.1 & 855 & 36.0 & 790 \\
\hline Mix of highly hard fat-oil with cotton oil at $85: 15$ & 40.5 & 708 & 34.5 & 560 \\
\hline
\end{tabular}

Table 4: Indicators of a mix of highly hard fat-oil with cotton oil at various parities of components before and after interesterification.

\section{Conclusion}

On the basis of hydrogenation cotton fat-oil to melting temperature $44-46^{\circ} \mathrm{C}$ and its subsequent interesterification with cotton oil can be received highly hard fat, close to the physical and chemical indicators to natural safe food oil.

\section{References}

1. Nechaev AP, Popov MP, Traubenberg SE (1998) Food Chemistry, part 2 M.: IK MGUPP.
2. Arutyuyan NS, Kornena EP, Yanova LI (1999) Technology of fat processing. M Pishepromizdat p. 452.

3. Oltiev AT, Majidova NK, Bobomurodov BN, Nuritdinov BS, Majidov KH, et al. (2015) New developments in the technology of intersterification of cotton oil and its products. Fat Oil Ind Sci J 4.

4. Tyutyunnikov BN (1992) Chemistry of fats. M.: Kolos p.156.

5. Oltiev AT, Majidov KH, Isabaev IB (2012) Impact of cotton palmitin enriched with soy phospholipids on resistance of margarine emulsions with different fat content. Chem Chem Technol Sci J Tashkent 2. 